\title{
Pentti Yrjölä
}

\section{Aikuiskasvatus valtion vuoden 1982 budjetissa}

Ensi vuoden valtion budjetin loppusumma on noin 65000 milj. mk, josta opetus, tiede ja kulttuuri kuluttavat noin 11000 milj. (17\%). Tästä summasta yleissivistävä opetus saa noin 4500 milj. ammattiopetus 2100 milj. ja korkeakouluopetus 1400 milj. mk. Aikuiskoulutuksen käyttöön on osoitettu 1049 milj. sekä kirjastoille, arkistoille ja museoille yhteensä 360 milj. mk. Aikuiskoulutuksen osuus koko opetus-, tiede- ja kulttuurialoille osoitetuista varoista oli $9,5 \%$.

Budjetin yleisperusteluissa todetaan, että aikuiskoulutuksen kehittämistä valmistellaan valtioneuvoston v. 1978 tekemän periaatepäätöksen mukaisesti tavoitteena jatkuvaan koulutukseen perustuva kokonaisuus, jossa eri koulutusasteet kiinteästi niveltyvät toisiinsa ja joustava opiskelu on mahdollista kaikkina ikäkausina. Perusteluissa todetaan lisäksi, että ammattikurssitoiminnan laajuus on tarkoitus pysyttää työllisyystilanteen ennakoidun heikkenemisen vuoksi v. 1982 edelleen korkeana. Tavanomaista työllisyyskoulutusta pyritään järjestämään 25000 henkilölle ja lisäksi työllisyyskoulutuksen laajentaminen kohdistuisi noin 8500 henkilöön. 
Aikuiskoulutukseen varattu määräraha jakaantuu seuraavasti:

\section{Ammattikurssit Yhteiskunnallinen \\ sivistystyö \\ - Kansanopistot \\ - Kansalais- ja työväenopistot \\ - Opintokeskukset \\ - Järjestöt \\ - Muut}

Yhteiskunnallisen sivistystyön osalta on esitetty valtionapulakien muuttamista siten, että ko. laitosten henkilöstön hyväksyminen valtionapuun oikeuttavaksi tapahtuisi vain valtion tulo- ja menoarvion rajoissa. Uusia toimia ei juurikaan ole budjetissa esitetty valtionavun piiriin. Valtionapuun oikeuttavaksi uudeksi opintokeskukseksi esitetään Kokoomusta lähellä olevaa Kansalaisten Opintokeskusta.

Muutamina hajahavaintoina aikuiskasvatusta lähellä olevina toimintamuotoina tai varsinaisesti siihen kuuluvina voidaan todeta, että

- oppisopimukseen perustuvalle ammattikoulutukselle on luvassa 28 milj. mk,

- kesäyliopistotoimintaan 2,3 milj. mk,

- korkeakoulujen täydennyskoulutuksen ja avoimen korkeakoulutuksen kehittämiseen 1,1 milj. mk ja

- ammatillisen kirjeopetuksen järjestämiseen on varattu 4 milj. mk.

Aikuiskasvatuksen yliopistollisen opetuksen kehittymisen perusedellytykset näyttävät tulevana vuonna myönteisiltä, sillä Tampereen yliopiston Aikuis- ja nuorisokasvatuksen laitokseen on luvassa peruspalkkainen aikuiskasvatuksen apulaisprofessorin virka. 